\title{
Review
}

\section{The last man takes LSD: Foucault and the end of revolution}

\author{
Mitchell Dean and Daniel Zamora \\ Verso, New York, 2021, 238pp., ISBN: 978-1839761393
}

Contemporary Political Theory (2023) 22, S10-S13. https://doi.org/10.1057/s41296021-00538-1; published online 21 January 2022

I'll admit it: I was drawn in by the title. And what scholar of Foucault wouldn't be intrigued by it? In this astonishingly readable new study, Mitchell Dean and Daniel Zamora creatively explore how neoliberalism, 'at least as an ideal or a political imaginary' (p. 209), seduced Foucault with its apparent break from various aspects of the disciplinary and biopolitical forms of power of which he was so critical. Appealing to his theoretical, political, and personal sensibilities, the authors argue, neoliberalism attractively offered an alternative conception of subjectivity, and seemed to entail an active effort to newly fashion practices of freedom, and the construction of the market as a mode of 'veridiction' of the state. Thus, for Foucault, neoliberalism was 'a way of governing that sought to maximize the autonomy of individuals in their own self-definition and self-creation and resist the subjection/subjectification of the welfare state and human sciences' (p. 209). Certainly, the effort to offer a rich account of the context for, as well as the nuances of, Foucault's positive appraisal of a certain strand of neoliberalism - and to grapple with its legacy - constitutes the heart of this book.

The authors begin, however, by delivering on the promise of their title to delve into Foucault's own experiments with 'self-definition and self-creation' specifically, his exploration of the boundaries of the self by way of 'limit experiences'. In spring of 1975 in Death Valley, Foucault - led by a couple of young gay Americans - became the 'last man' to dabble in LSD: 'last', in one sense, that he was late to the party (so late that it was almost over). Acid trips in the interest of self-discovery had long since seen their heyday; and a cult classic Italian film, featuring an orgy in the desert, had even been filmed at this same location in 1968, bearing its name (Zabriskie Point). What was Foucault doing reliving the good old days - this radical theorist who expressed the desire to intervene in the present by writing books that would become true only after they had been written?

Dean and Zamora energetically take on the task of filling in the political and intellectual context for the shift that took place in Foucault's thinking in the mid-

(C) 2021 The Author(s), under exclusive licence to Springer Nature Limited. 1470-8914 Contemporary Political Theory Vol. 22, S1, S10-S13

www.palgrave.com/journals 
'70s - exemplified by the way that he dramatically scrapped and completely rethought the remaining three volumes of The History of Sexuality after this famous LSD trip. His turn from a critique of disciplinary power to a hermeneutics of the self - specifically, in relation to new ways of thinking about resistance beyond the model of revolution - was closely associated with his attempt to use neoliberalism to serve his 'ambition...to invent a left governmentality' (p. 37). For the last decade of his life, the authors explain, Foucault was more decidedly anti-Marxist in his intellectual work and political activism, due to Marxism's emphasis on the state as the locus of political action and social transformation. This was connected to his conviction that the era of revolutionary politics was over, and his assessment, ten years later, that the events of May " 68 signified a crucial turning point in our conceptions of power and the central problematic of politics. With the clarity of his new emphasis on how subjects are shaped, and everyday acts of resistance, Foucault could see how, in ' 68 , new modes of governmentality were overtaking the sovereignty of the state, and technologies of the self replacing the sovereignty of the subject.

Dean and Zamora suggest that the 'original laboratory' for these ideas (p. 80) was Foucault's radical critique, dating back to the ' $60 \mathrm{~s}$, of the function of the author in a text. By overthrowing the author - ending the quest to interpret their intentions - the text was opened up to a plurality of potential meanings, and readers were empowered to use it 'to transform themselves' (p. 86). Similarly, politics after ' 68 was supposed to be about desubjectification and experimentation. Challenging power meant subverting normalization and the forms of individualization promoted by the state by creating new modes of subjectivity; resistance now meant reinventing ourselves. 'Revolution' was the pursuit of ' $[t]$ iny transformations' that could 'somehow have aggregate effects that will in the end provoke profound shifts in society' (p. 155). So, if this was the end of revolution as we once knew it, for Foucault, it certainly wasn't the end of meaningful revolt(s) - rather, it was a change in tactic, target, and expectations.

All of this helps set the stage for Foucault's controversial embrace of neoliberalism. Dean and Zamora are adamant about specifying which 'neoliberalism' Foucault found compelling - a contemporary form of economic liberalism insisting that neither was he an uncritical supporter of all forms of neoliberalism, nor was all of his work tainted by neoliberal assumptions. Given his abhorrence of disciplinary socialist policies and his eagerness to conceive of an alternative to a postwar socialist Left, Foucault was interested in neoliberalism as a framework for rethinking the art of government, conceiving anew of a left governmentality that would shed the problematic of the State. The 'advanced liberalism' of French President Giscard d'Estaing appeared to Foucault as a much less normative, more tolerant mode of governing; Giscard d'Estaing's negative income tax system would promote equal opportunity while creating space free from being 'governed too much'. And the focus of American neoliberalism on constructing choice seemed

(c) 2021 The Author(s), under exclusive licence to Springer Nature Limited. 1470-8914 Contemporary S11 Political Theory Vol. 22, S1, S10-S13 
highly preferable to the welfare state's 'production of subjectivity' (p. 212). Foucault imagined that a neoliberal governmentality could make room for the experimentation, plurality, anti-normativity, and acts of resistance on the margins in which he was so invested as a new mode of politics.

By doing the work of carefully situating Foucault's uptake of neoliberalism in its historical, intellectual, and political context, and clarifying his relationship to this group of theories by putting qualifications on exactly which 'neoliberalism' Foucault endorsed, the authors make a valuable contribution to the ongoing debate over this aspect of the Foucauldian legacy. Unlike other commentators, Dean and Zamora strive to avoid the obfuscation that results from 'project[ing]... their own interpretations of neoliberalism' onto the matter (p. 55); they make an honest effort to appreciate the complexity of neoliberalism's intellectual history, policies, and practical outcomes. But they are also unafraid of acknowledging the seriousness of Foucault's engagement with neoliberalism, recognizing the important role it played in motivating the shift in focus of his work - and, of identifying his missteps. Though he correctly predicted that the market would be the mode of veridiction of the government under neoliberalism (assessing whether it was governing correctly and/or too much), he did not foresee that the 'relation of self to self' would 'become the essential weapon of neoliberal governing and politics', rather than emerging as a key site of resistance to disciplinary measures (p. 231). In a devastating twist on his celebration of the 'ordeal' or 'épreuve' (test) as 'a mode of producing truth that presages a self-transformation' (p. 114), welfare recipients, under neoliberal policies, would be subjected to a panoply of mandatory 'ideals' to prove their worth - and, supposedly to help them to exercise 'rational choice'. Foucault somehow did not predict how coercive disciplinary measures would sneak back in at the sites of neoliberal theory and policy that he took to be so promising for a politics of resistance.

It is by confronting the failures of Foucault's neoliberal passion that Dean and Zamora make their boldest intervention into our reception of his work today. They reckon with his disastrously shortsighted promotion of neoliberalism from multiple perspectives: his experimental ethos explains how he delved into neoliberalism, they suggest, without working out its implications. However, he was also able to achieve special insights into neoliberalism, they maintain, 'precisely because he allowed himself to come so very close to it' (p. 208). They ultimately insist that we move beyond Foucault, however, with their stunning assertion that any contemporary relevance of his thought lies in what it 'fails to observe', and 'what it perversely anticipates' (p. 231). We must work through his hold on us, they claim, releasing ourselves from the grip that he still has on our critical imagination, if we are to imagine ways out of our present neoliberal mess. This assessment, if seemingly harsh, is clearly informed by the urgency of our current crises, and a thorough critical analysis of Foucault's experiment with neoliberalism. 
Do desperate times call for such desperate measures? Should we not be experimenters? Perhaps one thing that we learn from Foucault is the importance of transcending our limits; we can 'take LSD' with him to move beyond him, without taking it as an emblem of the mode of politics we should embrace, or forgetting the lessons of the last several decades. Foucault himself would want us to break free from the theoretical and political constraints that have produced, for us, further catastrophes of inequality, discrimination, and domination.

Publisher's Note Springer Nature remains neutral with regard to jurisdictional claims in published maps and institutional affiliations.

Nicole Yokum

University of Toronto, St. George, ON M5R 2M8, Canada

nicole.yokum@utoronto.ca 